\title{
Geographical clustering of risk factors and lifestyle for coronary heart disease in the Scottish Heart Health Study
}

\author{
I K Crombie, W C S Smith, R Tavendale, Hugh Tunstall-Pedoe
}

\begin{abstract}
A large cross sectional study, the Scottish Heart Health Study, of 10359 men and women from 22 districts of Scotland was undertaken to try to explain the geographical variation of coronary heart disease mortality. Analysis by district showed that of the classic risk factors only cigarette smoking was strongly associated with heart disease mortality among both men and women. Mean diastolic blood pressure was weakly associated with rates among men and high density lipoprotein cholesterol showed a strong negative association among women. Total cholesterol showed a weak negative association with heart disease mortality, but, because the serum concentrations of cholesterol were uniformly high in all districts, a strong association with mortality would not be expected. In both men and women many dietary factors showed moderate or strong associations with mortality from coronary heart disease in a district-of these a low consumption of vitamin $\mathbf{C}$ was most notable. Other factors associated with heart disease included alcohol consumption and serum triglycerides among men, and obesity, physical activity, and serum triglycerides among women. Many factors associated with heart disease showed strong intercorrelations. Clustering of risk factors (including smoking, alcohol, and diet among men, and smoking, diet, and obesity among women) was associated with much of the regional variation in heart disease mortality in Scotland.
\end{abstract}

Cardiovascular

Epidemiology Unit, Ninewells Hospital and Medical School, Dundee

I K Crombie

W C S Smith

$R$ Tavendale

H Tunstall-Pedoe

Correspondence to Dr I K Crombie,

Department of Community

Medicine, Ninewells

School, Dundee DD1 9SY

Accepted for publication

15 May 1990
Regional variation in coronary heart disease mortality has been investigated for many years in the search for clues to the causation of this disease. The early studies were largely of physical factors such as water hardness ${ }^{12}$ and climate, ${ }^{3}$ and used data from the decennial censuses merely to control for socioeconomic variables. However, more recent studies have been interested in the ability of the socioeconomic variables to explain geographical variation. ${ }^{4-6}$ There is increasing interest in the association of socioeconomic factors with mortality $^{78}$ particularly because the social class gradient of coronary heart disease mortality is widening. ${ }^{910}$

These studies have been important in providing stimulus and direction to further research. However, they leave unanswered the question of which individual lifestyle features underlie the socioeconomic factors and thus the regional variation. One previous study, which covered all mainland Britain, measured risk factors in individuals to explain regional variation. ${ }^{11}$

We showed that Scotland has a complex and interesting geographical pattern of mortality from coronary heart disease ${ }^{12}$ and that a large part of this can be explained by socioeconomic variables, ${ }^{6}$ though in contrast with England and Wales water hardness is not important. ${ }^{13}$ One of the major aims of the Scottish Heart Health Study was to explain the geographical pattern in terms of individual risk factors. ${ }^{14}$ Two papers on the risk factor levels have recently been published. ${ }^{15} 16$ This paper reports an analysis of regional data to identify the risk factors associated with coronary heart disease and data on risk factors mediating the association of the socioeconomic variables with heart disease.

\section{Patients and methods \\ STUDY DESIGN}

The study was conducted in local government districts throughout mainland Scotland. Twenty one districts were selected and one, Glasgow City, which was considerably larger than the next largest, was partitioned into two parts, giving twenty two study districts. The selection of districts ensured good geographical spread, a range of urban/rural composition, and coverage of the range of mortality for coronary heart disease. ${ }^{14}$

In each district people were selected by a two-stage cluster sampling design. ${ }^{17} \mathrm{~A}$ random sample of the general practitioners was drawn and their patients sub-sampled to yield a target of 450 people aged $40-59$ years consisting of equal numbers of men and women and also equal numbers in the 10 year age groups 40 49 and 50-59. Two of the study districts, Edinburgh and North Glasgow, participated in the overlapping World Health Organisation MONICA study, ${ }^{18}$ and included a total of 30 
general practitioners and a target of 800 people in this age range.

\section{MEASUREMENTS}

Each person completed an extensive questionnaire that sought information on biographical and economic details, past medical history, standardised respiratory questions, exercise, smoking, diet, alcohol consumption, diet, personality type, and health knowledge. The questionnaire was completed before the individual attended for examination at a local clinic; it was checked for completeness at the clinic. A team of three nurses measured height, weight, blood pressure (the average of two readings with a random zero sphygmomanometer), and carbon monoxide in expired air; an electrocardiogram was also recorded. A sample of venous blood was taken and arrangements were made for a 24 hour urine sample to be collected. Full details of the procedure have been published elsewhere. ${ }^{14}$ The fieldwork was carried out between 1984 and 1986.

\section{DEFINITIONS}

Hypertension: diastolic blood pressure of at least $100 \mathrm{~mm} \mathrm{Hg}$.

Current smoker: self-report of occasional or regular cigarette smoking.

Heavy smoker: self-report of 20 or more cigarettes per day.

Heavy drinker: reported consumption of at least 40 units per week for men and 20 units per week for women (one unit equals a half pint of beer, a measure of spirits, or a glass of wine).

Obesity: body mass index (weight divided by height squared of at least $30.0 \mathrm{~kg} / \mathrm{m}^{2}$ for men and $28.6 \mathrm{~kg} / \mathrm{m}^{2}$ for women).

\section{STATISTICAL ANALYSIS}

Correlations between the mean values of each variable for the districts and the district standardised mortality ratios for coronary heart disease were assessed by Spearman's rank correlation coefficient. Given that there were 22 study districts, coefficients larger than 0.425 were significant at the $5 \%$ level and those larger than 0.498 were' significant at the $1 \%$ level. Rank correlation was used to preclude difficulty with variables that were not normally distributed. The variables selected for inclusion in the multiple linear regression analyses were approximately normally distributed.

\section{CORONARY HEART DISEASE MORTALITY}

Data on all deaths from coronary heart disease (ICD 410-414, 9th Revision) for the age groups 35-64 years and the period 1979-83 were obtained from the Registrar General (Scotland). We calculated standardised mortality ratios separately for each sex using 5 year age specific mortality rates where the standardised mortality ratio for the whole of Scotland is defined as 100 .

\section{Results}

One major aim of the Scottish Heart Health Study was to determine the extent to which the major risk factors could explain the geographical variation of coronary heart disease in Scotland. This variation was described in a previous paper. ${ }^{6}$ In brief it showed that mortality was in general high in the West and low in the East. Further, in west central Scotland there was a grouping of eight districts with very high mortality that surrounded two other districts with very low mortality from heart disease. This variation is explored in table 1 which shows the rank correlations between standardised mortality ratios for heart disease and serum cholesterol, smoking, and blood pressure separately for men and women. Cigarette smoking stands out as being most strongly associated with heart disease mortality for both men and women. The only other coefficients approaching statistical significance were diastolic pressure in men and high density lipoprotein cholesterol in women (significant at $1 \%$ ). The latter is a curious result because of the large difference in the size of the coefficients for men and women. Total cholesterol showed a weak negative correlation with heart disease mortality. However, the district mean total cholesterol concentrations were uniformly high for men (range $6 \cdot 1-6.5 \mathrm{mmol} / \mathrm{l}$ ) and women $(6.3-6.9 \mathrm{mmol} / \mathrm{l})$ and would not be expected to contribute to the regional variation in mortality.

Table 2 shows the relation between the socioeconomic variables obtained from the census that were associated with heart disease and the major risk factors. Two census variables, percentage male unemployment and percentage social classes III-V were selected because they had independent explanatory effects in an earlier study. ${ }^{6}$ The importance of these variables was confirmed in the present survey data (table 2) and, as previously, male unemployment is more strongly associated with heart disease mortality. The relation between these social variables and the major risk factors for coronary heart disease also shows interesting results. Among men these social factors are strongly associated with mean diastolic blood pressure and the percentage of

Table 1 Correlation of the major risk factors with mortality from coronary heart disease

\begin{tabular}{|c|c|c|}
\hline & \multicolumn{2}{|c|}{$\begin{array}{l}\text { Correlations }{ }^{\star} \text { with heart } \\
\text { disease }\end{array}$} \\
\hline & Male & Female \\
\hline $\begin{array}{l}\text { Blood pressure: } \\
\text { Mean systolic } \\
\text { Mean diastolic } \\
\text { Percentage with hypertension } \dagger\end{array}$ & $\begin{array}{l}0 \cdot 219 \\
0 \cdot 402 \\
0 \cdot 223\end{array}$ & $\begin{array}{l}0 \cdot 011 \\
0 \cdot 234 \\
0 \cdot 299\end{array}$ \\
\hline $\begin{array}{l}\text { Total cholesterol: } \\
\text { Mean } \\
\text { Percentage }>6.5 \mathrm{mmol} / 1\end{array}$ & $\begin{array}{l}-0.129 \\
-0.254\end{array}$ & $\begin{array}{l}-0.207 \\
-0.116\end{array}$ \\
\hline - Mean HDL cholesterol & $-0 \cdot 172$ & $-0.609 \ddagger$ \\
\hline $\begin{array}{l}\text { Cigarette smoking: } \\
\text { Percentage current smokers } \\
\text { Percentage heavy smokers } \dagger\end{array}$ & $\begin{array}{l}0.655 \ddagger \\
0.574 \ddagger\end{array}$ & $\begin{array}{l}0.834 \ddagger \\
0.758 \ddagger\end{array}$ \\
\hline
\end{tabular}

«Spearman's rank correlation coefficients.

†Hypertension and heavy smoking are defined in Patients and methods.

$\ddagger$ Significant at least at the $5 \%$ level $(p<0.05)$. 
Table 2 Relation between important social variables and coronary heart disease and its risk factors among men and women

\begin{tabular}{lcccccc}
\hline & \multicolumn{2}{c}{ Percentage unemployed } & & \multicolumn{2}{l}{ Percentage social class III-V } \\
\cline { 2 - 3 } & Male & Female & & Male & Female \\
\hline Coronary heart disease mortality & & $0.760 \dagger$ & $0.775 \dagger$ & & $0.598 \dagger$ & $0.585 \dagger$ \\
Systolic blood pressure & 0.230 & 0.094 & & $0.524 \dagger$ & 0.309 \\
Diastolic blood pressure & $0.506 \dagger$ & 0.283 & & $0.571 \dagger$ & $0.475 \dagger$ \\
Percentage current smokers & $0.783 \dagger$ & $0.686 \dagger$ & & $0.800 \dagger$ & $0.816 \dagger$ \\
Total cholesterol & -0.177 & -0.177 & & -0.114 & 0.042 \\
High density lipoprotein cholesterol & -0.269 & -0.380 & & -0.388 & $-0.609 \dagger$ \\
\hline
\end{tabular}

«Male unemployment rates have been used.

† Significant at least at the $5 \%$ level (p $<0.05)$.

current smokers. Among women only the percentage of current smokers was consistently associated with the social factors, with high density lipoprotein cholesterol and diastolic blood pressure being significantly associated with only one social factor. It is again interesting that total cholesterol shows weak, mainly negative associations with the social factors.

Table 3 shows the association of coronary heart disease mortality with dietary variables. The variables shown are either individual foodstuffs recorded on a food frequency questionnaire or nutrient values estimated from the questionnaire by a method described elsewhere. ${ }^{19}$ Several variables show strong associations with heart disease, and, as might be expected, all these variables are themselves highly correlated. These dietary associations are similar for men and women.

In contrast with the similarity seen with diet there were considerable differences between the sexes in the association of heart disease mortality with the other lifestyle features (table 4). Among men there is a moderate positive association with alcohol but for women it is weak and negative. In fact alcohol consumption in women was low with little difference between the districts, so that no association would be expected. Strong positive associations with obesity and strenuous physical activity at work and leisure are only seen among women.

Several biochemical variables showed associations with heart disease mortality (table 5). Of these creatinine, both serum and urinary, showed strong associations only in men. The strong negative association with urinary potassium was found for both sexes. Only weak associations were found for urinary sodium and plasma fibrinogen.

The important questions that the univariate

Table 3 Association of dietary variables with mortality from coronary heart disease

\begin{tabular}{lcc}
\hline & Male & Female \\
\hline Percentage eating: & & \\
No fruit & $0.588^{\star}$ & $0.537^{\star}$ \\
No green vegetables & $0.491^{\star}$ & $0.431^{\star}$ \\
White bread only & $0.611^{\star}$ & $0.666^{\star}$ \\
Lard $\geq$ twice/week & $0.476^{\star}$ & $0.638^{\star}$ \\
Average amount per week: & $0.563^{\star}$ & $0.573^{\star}$ \\
$\quad$ Eggs & $0.474^{\star}$ & $0.572^{\star}$ \\
Sausages & & \\
Estimated nutritional means: & $-0.731^{\star}$ & $-0.634^{\star}$ \\
Vitamin C & $-0.471^{\star}$ & $-0.633^{\star}$ \\
Vegetable fibre & 0.134 & 0.382 \\
Total fat &
\end{tabular}

*Significant at least at the $5 \%$ level $(p<0.05)$.
Table 4 Association of other lifestyle features with mortality from coronary heart disease

\begin{tabular}{lrr}
\hline & Male & Female \\
\hline Alcohol: & & \\
$\quad$ Percentage heavy drinkers & $0.519 \dagger$ & -0.358 \\
Median alcohol & $0.446 \dagger$ & -0.269 \\
Obesity: & & \\
$\quad$ Percentage obese & 0.171 & $0.732 \dagger$ \\
$\quad$ Mean BMI & -0.028 & $0.624 \dagger$ \\
Physical activity: & & \\
$\quad$ Percentage strenuous at work & 0.355 & $0.782 \dagger$ \\
Percentage strenuous at leisure & 0.147 & $0.541 \dagger$ \\
\hline
\end{tabular}

*Median alcohol consumption was used rather than the mean because the distribution of alcohol values was highly skewed. † Significant at least at the $5 \%$ level $(p<0.05)$.

BMI, body mass index.

Table 5 Association of biochemical variables with mortality from coronary heart disease

\begin{tabular}{lcc}
\hline & Male & Female \\
\hline Urinary creatinine & $-0.644^{\star}$ & -0.273 \\
Serum creatinine & $-0.500^{\star}$ & -0.047 \\
Serum triglycerides & $0.472^{\star}$ & $0.600^{\star}$ \\
Serum uric acid & $-0.434^{\star}$ & -0.073 \\
Urinary potassium & $-0.556^{\star}$ & $-0.705^{\star}$ \\
\hline
\end{tabular}

$\star$ Significant at least at the $5 \%$ level $(p<0.05)$.

analyses pose are the extent to which the variables are interrelated and to which they have independent explanatory effects for heart disease mortality. The answer to the first is that there is a high degree of interrelation as shown in table 6. For example, among men the percentage of current smokers is strongly associated with percentage unemployment, mean urinary potassium, mean number of eggs, percentage regularly eating lard, and mean vitamin C Further the pattern of correlation of vitamin $C$ with the other variables is almost identical to that which percentage current smokers has with these variables and the same is true of male unemployment, consumption of eggs, and lard. It seems that there are a set of social, smoking, and dietary factors that are associated with heart disease mortality and which vary in concert between districts. When a multiple regression model is fitted the first of those variables to enter will explain (in a statistical sense) a major part of the effects of the others, though in reality they may have independent effects.

Rather than fitting a model with just one of these variables we selected the three variables (percentage unemployed, percentage current smokers, and mean vitamin C) that showed the largest univariate correlations with heart disease mortality. Then three separate models were fitted, each having one of the selected variables forced into the model. The association between the remaining unexplained variation in heart disease and the variables not in the model was assessed from the magnitude of their partial correlations with heart disease mortality. Comparison of the three models identified the variables that show a consistent association with heart disease mortality irrespective of the first independent variable fitted. Thus table 7 shows that for men the percentage of heavy drinkers and mean egg consumption emerge consistently as exerting an independent effect. 


\begin{tabular}{|c|c|c|c|c|c|c|c|c|c|c|}
\hline & $\begin{array}{l}\text { Heart } \\
\text { disease }\end{array}$ & $\begin{array}{l}\text { Percentage } \\
\text { current } \\
\text { smokers }\end{array}$ & $\begin{array}{l}\text { Mean } \\
\text { diastolic } \\
\text { pressure }\end{array}$ & $\begin{array}{l}\text { Percentage } \\
\text { male } \\
\text { un- } \\
\text { employment }\end{array}$ & $\begin{array}{l}\text { Urinary } \\
\text { potassium }\end{array}$ & $\begin{array}{l}\text { Percentage } \\
\text { heavy } \\
\text { drinkers }\end{array}$ & $\begin{array}{l}\text { Urinary } \\
\text { creatinine }\end{array}$ & $\begin{array}{l}\text { Serum } \\
\text { creatinine }\end{array}$ & Eggs & Lard \\
\hline $\begin{array}{l}\text { Percentage current smokers } \\
\text { Mean diastolic pressure } \\
\text { Percentage male unemployment } \\
\text { Urinary potassium } \\
\text { Percentage heavy drinkers } \\
\text { Urinary creatinine } \\
\text { Serum creatinine } \\
\text { Eggs } \\
\text { Lard } \\
\text { Vitamin C }\end{array}$ & $\begin{array}{l}0.655^{\star} \\
0.402 \\
0.760^{\star} \\
-0.556^{\star} \\
0.519^{\star} \\
-0.644^{\star} \\
-0.500^{\star} \\
0.563^{\star} \\
0.476 \\
-0.730^{\star}\end{array}$ & $\begin{array}{c}0.431 \\
0.783^{\star} \\
-0.708^{\star} \\
0.467 \\
-0.503^{\star} \\
-0.453 \\
0.7366^{\star} \\
0.859^{\star} \\
-0.781^{\star}\end{array}$ & $\begin{array}{r}0.506^{\star} \\
-0.625^{\star} \\
0.322 \\
-0.353 \\
-0.357 \\
0.317 \\
0.337 \\
-0.477\end{array}$ & $\begin{array}{c}-0.595^{\star} \\
0.492 \\
-0.507^{\star} \\
-0.356 \\
0.725^{\star} \\
0.698^{\star} \\
-0.774^{\star}\end{array}$ & $\begin{array}{c}-0.478 \\
0.680^{\star} \\
0.436 \\
-0.600^{\star} \\
-0.576^{\star} \\
0.720^{\star}\end{array}$ & $\begin{array}{c}-0.583^{\star} \\
-0.617^{\star} \\
0.277 \\
0.219 \\
-0.464\end{array}$ & $\begin{array}{c}0.473 \\
-0.568 \star \\
-0.228 \\
0.527^{\star}\end{array}$ & $\begin{array}{r}-0.355 \\
-0.338 \\
0.457\end{array}$ & $\begin{array}{r}0.776^{\star} \\
-0.716^{\star}\end{array}$ & $-0.755^{\star}$ \\
\hline
\end{tabular}

«Significant at $t$ : $: 1 \%$ level $(p<0.01)$.

A similar analysis of the data for women showed a similar pattern in which groups of factors were closely associated (data not shown). Smoking correlated positively with obesity, consumption of lard and white bread, and negatively with urinary potassium and vitamin $\mathrm{C}$. The multiple regression models for women produced much more complicated results than those for men (table 7) with many variables showing an association with heart disease mortality that was independent of the first variable fitted. This complexity is difficult to interpret in detail but it suggests that there may be more than one grouping of lifestyle factors associated with heart disease mortality.

\section{Discussion}

This study has found a complex pattern of associations between coronary heart disease mortality and a variety of social, lifestyle, and biochemical variables measured at a regional level. One advantage of this study is that, because it included women as well as men, the results in the two sexes can be compared. Of the classic risk factors only smoking emerges as a strong explanatory variable and its effect is stronger for women than men. A limitation of this study is that the analysis is based on data for groups not individuals. It will only identify factors that explain regional differences and consequently factors that are important at an individual level would not be identified if they varied little between regions. There is, however, a large geographical variation in the mortality from coronary heart disease in Scotland, and the purpose of this paper was to try to explain it.

Table 7 Regression models fitted by selecting a single variable

\begin{tabular}{|c|c|}
\hline Variable fitted & Variables with large $e^{\star}$ partial correlation coefficients \\
\hline $\begin{array}{l}\text { Males: } \\
\text { Unemployment } \\
\text { Percentage current smokers } \\
\text { Vitamin C }\end{array}$ & $\begin{array}{l}\text { Percentage heavy drinkers, vitamin C, eggs } \\
\text { Percentage heavy drinkers, urinary creatinine, eggs } \\
\text { Percentage heavy drinkers, eggs }\end{array}$ \\
\hline $\begin{array}{l}\text { Females: } \\
\text { Percentage current smokers }\end{array}$ & $\begin{array}{l}\text { Vigorous work, heavy drinking, urinary potassium, mean } \\
\text { systolic, HDL-cholesterol }\end{array}$ \\
\hline Percentage unemployed & $\begin{array}{l}\text { Percentage current smokers, HDL-cholesterol, vigorous } \\
\text { work, lard, triglycerides, heavy drinking, urinary } \\
\text { potassium, white bread, serum creatinine, obesity. }\end{array}$ \\
\hline Vitamin C & $\begin{array}{l}\text { Percentage obese, percentage heavy drinkers, vigorous } \\
\text { work, percentage current smokers, urinary potassium, } \\
\text { HDL-cholesterol, trigylcerides, percentage } \\
\text { unemployment, white bread, sausages, eggs, lard }\end{array}$ \\
\hline
\end{tabular}

$\star$ Selected as being significant at the $10 \%$ level $(\mathrm{p}<0 \cdot 1)$.

HDL, high density lipoprotein.
The only comparable cross sectional study is i the British Regional Heart Study, which inves- $\overrightarrow{0}$ tigated men only. It found an association with smoking but it also found a rather stronger effect with systolic blood pressure. ${ }^{11}$ The range of systolic pressure among the 24 towns was considerable (from 136 to $153 \mathrm{~mm} \mathrm{Hg}$ ), whereas the range was narrower in the present study (129 to $138 \mathrm{~mm} \mathrm{Hg}$ ). The present study found that only mean diastolic blood pressure among men showed a moderate association with mortality from heart disease. In neither study was there any association between regional values of total cholesterol or high density lipoprotein cholesterol and heart disease mortality in men. Cholesterol concentrations in Scotland are uniformly high ${ }^{16}$ and do not contribute to the regional variation. These high values of cholesterol are important in explaining Scotland's position at the top of the world league for heart disease mortality. ${ }^{20}{ }^{21}$ In women too total cholesterol was not associated with coronary heart disease mortality, so that the observation of a strong negative association of high density lipoprotein cholesterol is interesting.

The importance of social factors in the explanation of the geographical variation in mortality from coronary heart disease raises the question of the lifestyle features that underlie this. The difficulty here is that many lifestyle features vary in concert. For example, a diet containing a high content of saturated fat foods (lard, sausages, and eggs) tends also to be one low in fibre, fresh fruit, and green vegetables. Thus all these variables are associated with mortality from coronary heart disease in both men and women. One unexpected finding was the inverse relation between serum creatinine and mortality from heart disease among men. High serum creatinine, through its association with hypertension, might be expected to correlate positively with heart disease mortality. However, the association between serum creatinine and mean diastolic blood pressure was weak, non-significant, and inverse. Further, serum creatine is not just affected by renal function but also by diet. ${ }^{22}$ Further, mean serum creatinine shows moderate negative associations with current smoking, unemployment, and the consumption of eggs and lard.

In these circumstances it is difficult and unwise to choose a particular factor and attribute to it the variation in mortality. Thus 
although vitamin $\mathrm{C}$ emerges as the dietary factor most strongly associated with mortality its effects are interlinked with the other dietary factors and with cigarette smoking. The association of alcohol and of egg consumption with mortality in men could in part be due to an association with other factors but in the multiple regression models both exerted consistent independent effects.

The pattern of associations of variables with themselves and with heart disease mortality in women is as complex as that for men. There was considerable overlap with the men in the variables showing a strong association with heart disease mortality; however, some variables (obesity and high density lipoprotein cholesterol) do so only in women. A review of myocardial infarction in women concluded that the classic risk factors for men were also important for women. ${ }^{23}$ The review also suggested that high density lipoprotein cholesterol and triglycerides were also of importance but obesity less so. The finding from this study of a grouping of factors of which obesity was a prominent member could suggest that obesity may be more important than previously recognised or that the risk factors among Scottish women may differ from those elsewhere. This could be important in view of the specially high mortality from heart disease among Scottish women. ${ }^{20}$

The Scottish Heart Health Study was funded predominantly by the Scottish Home and Health Department Chief Scientist Organisation who are not responsible for any of the opinions expressed. Additional grants were awarded by the Independent Scientific Committee on Smoking and Health, the Chest Heart and Stroke Association, and the British Heart Foundation. We acknowledge the cooperation of twelve Health Boards, 260 general practitioners, and their staffs and patients; Dr G D O Lowe and Dr R A Riemersma for their contribution to the laboratory analyses, and the work of the staff involved in the study directly, in particular Mr M Irving for the computing study directly, in particular Mr M Irving for the computing
assistance and the nurses, laboratory, data, and secretarial staff.

1 Morris JN, Crawford MD, Heady JA. Hardness of local water-supplies and mortality from cardiovascular disease. Lancet 1961; i:860-2.

2 Crawford MD, Gardner MJ, Morris JN. Mortality and hardness of local water-supplies. Lancet 1968;i:827-31.
3 West RR, Lowe CR. Mortality from ischaemic heart disease-inter-town variation and its association with climate in England and Wales. Int J Epidemiol 1976;5:195-201.

4 Gardner MJ. Using the environment to explain and predict mortality. JR Statist Soc A 1973;136:421-40.

5 Pocock SJ, Shaper AG, Cook DG, et al. British Regional Heart Study: geographic variations in cardiovascular mortality, and the role of water quality. $\mathrm{Br}$ Med $J$ 1980;280:1243-9.

6 Crombie IK, Kenicer MB, Smith WCS, Tunstall-Pedoe HD. Unemployment, socioenvironmental factors, and coronary heart disease in Scotland. Br Heart J 1989; 61:172-7.

7 Department of Health and Social Security. Inequalities in health. Report of a research working group. London: DHSS, 1980.

8 Whitehead M. The health divide: inequalities in health in the 1980s. London: Health Education Council, 1987.

9 Marmot MG, Adelstein AM, Robinson N, Rose GA. Changing social class distribution of heart disease. Br Med J 1978;ii:1109-12.

10 Marmot MG, McDowall ME. Mortality decline and widening social inequalities. Lancet 1986:ii:274-6.

11 Shaper AG, Pocock SJ, Walker M, Cohen NM, Wale CJ, Thomson AG. British Regional Heart Study: cardiovascular risk factors in middle-aged men in 24 towns. $B r$ Med J 1981;283:179-86.

12 Crombie IK, Smith W.CS, Kenicer MB, Tunstall-Pedoe H. Geographical variation in coronary heart disease mortality in Scotland. Health Bull (Edinb) 1986;44:193-202.

13 Smith WCS, Crombie IK Coronary heart disease and water hardness in Scotland-is there a relationship. J Epidemiol Community Health 1987;41:227-8.

14 Smith WCS, Crombie IK, Tavendale R, Irving JM, Kenicer $M B$, Tunstall-Pedoe $H$. The Scottish Heart Health Study: objectives and development of methods. Health Bull (Edinb) 1987;45:211-7.

15 Smith WCS, Tunstall-Pedoe $H$, Crombie IK, Tavendale $R$ Concomitants of excess coronary death: findings from 10,359 men and women in the Scottish Heart Health Study. Scott Med J 1989;34:550-6.

16 Tunstall-Pedoe H, Smith WCS, Crombie IK, Tavendale R. Coronary risk factors and lifestyle variation across Scotland: results from the Scottish Heart Health Study. Scott Med J 1989;34:556-60.

17 Crombie IK, Smith WCS, Irving JM, Tunstall-Pedoe HD. Experience with general practitioner lists as a sampling
frame for a survey of cardiovascular risk factors. The frame for a survey of cardio
Statistician 1989;38:25-31.

18 World MONICA Project Principal Investigators (prepared by $H$ Tunstall-Pedoe). The World Health Organisation MONICA Project (monitoring trends and diseases in cardiovascular disease): a major international collaboration. J Clin Epidemiol 1988;41:105-14.

19 Yarnell JWG, Fehily AM, Milbank JE, Sweetnam PE, Walker CC. A short dietary questionnaire for use in epidemiological survey: comparison with weighted dietary records. Hum Nutr Appl Nutr 1983;37A:103-12.

20 Tunstall-Pedoe H, Smith WCS, Crombie IK. Levels and trends of coronary heart disease mortality in Scotland compared with other countries. Health Bull (Edinb) 1986;44:153-61.

21 WHO MONICA Project. Geographical variation in the major risk factors of coronary heart disease in men and major risk factors of coronary heart disease in men and

22 Gabrie R. Time to scrap creatinine clearance? $\mathrm{Br} \mathrm{Med} \mathrm{J}$ 1986;293:1119-20.

23 Johansson S, Vedin A, Wilhelmsson C. Myocardial infarction in women. Epidemiol Rev 1983;5:67-95. 